DOI 10.18551/rjoas.2019-06.20

\title{
CAR LOAN BEHAVIOR AND CUSTOMER RETENTION
}

\author{
Putri Nadia Esa \\ School of Business, Bogor Agricultural University, Indonesia \\ Simanjuntak Megawati, Yuliati Lilik Noor \\ Department of Family and Consumer Sciences, Faculty of Human Ecology, \\ Bogor Agricultural University, Indonesia \\ *E-mail: nadiaesaputri22@gmail.com
}

\begin{abstract}
The purpose of this study is to identify customer characteristics, customer behavior, and customer retention in car loan companies. In this study used cross-sectional design as a method. Data obtained through an online survey are processed using a quantitative approach with descriptive analysis. The sampling technique in this study used purposive sampling, with 310 respondents obtained according to Slovin's calculation. The criteria for respondents are the customer who has a good history and already used car loan products or services at least once and for five years since the end of their credit period they never used credit again. Most of car loan companies' respondents are men with 31-40 years old and have married status. The education level of respondents is a bachelor degree with a job as an office employee who has expenditure Rp.4.100.000-5.000.000/month. Most of the respondents have one unit of the car with Toyota brand. For purchasing a car again, credit payment mechanism is still preferred than cash. Top of mind car loan companies is Company X, BCA Finance, and Mandiri Tunas Finance. Media information that is considered most useful for car loan companies is used sales dealer. Most of the respondents currently using BCA Finance because of this company have the interest and low installment. In line with this, the car loan program that considered attractive by respondents is special interest and installments. Regarding the customer retention, most of respondents are interested in reusing, recommending to others, and the company is a priority.
\end{abstract}

\section{KEY WORDS}

Costumer behavior, customer retention, car, loan company.

This time most companies focus on strategy for getting new customer compared to retain (Kurniawan 2018). If the companies focus on the strategy of retaining customer, many benefits will be obtained, one of them are the companies will have a loyal customer. Also, the adoption of a strategy that acquires a new customer is more expensive than the strategy of retaining customer (Griffin 1995).

One of the indicators for successful business in a competition is currently assessed by customer retention. This is a challenge by the companies how to keep their customer, so they do not move to competitors. Besides that the companies also need to think of new strategy so that customer will continue to use products or services and will be recommended to others. One marketing strategy that is usually used to build a long relationship between companies and customer is generally known as customer relationship management (Dawes 2009).

For a company that contributes to business line services, of course, it is a challenge in facing current competition. The company must be able to make their customer feel the benefit that is intangible when using their services. Also, the company needs to pay attention to the services provided for the customer because of excellent services indirectly show the positive image to the customer. When the customer feels happy to use the services of the company, they feel satisfied and will be making a repurchase. Kotler (2009) states that satisfaction is a happy feeling of someone because they compare the perceived performance 
with customer expectation.

The car loan company in this study is one of the companies in financial services with the main product of financing four-wheel vehicle. In the previous year, the business process strategy carried out by company $X$ focused on a strategy to get a new customer (customer acquisition). This can be seen from the portfolio of customer who has used credit in company X, almost $80 \%$ are a new customer, and $20 \%$ are existing customer. If the company only focus on how to get a new customer, it is possible that existing customer who has used products or services will switch to competitors.

Currently, there are two groups of an existing customer in company $X$ that are divided based on the parameter of late credit payment (overdue), priority customer (customer with good payment history) and non-priority customer (customer with lousy payment history). The priority is a group which, over the past five years tends to decline. Based on the description, this study is to identify customer characteristics, customer behavior, and customer retention in car loan companies.

\section{LITERATURE REVIEW}

Customer behavior is the study of individual, group or organization related to a process in selecting, securing, using, placing products or services, experience or idea to do what is desired and it is an effect (Hawkins et al. 2007). The scope of customer behavior includes many things because customer behavior is a study of the process when individual or group of people choose to use or not products or services to satisfy their needs or desire (Solomon 2007). Based on the definition, it can be concluded that customer behavior is the study of an individual or group in determining to choose, buy, use, and replace a products or services to achieve what is desired.

Lewis (2009) said that customer retention is a customer behavior to maintain something from the company because of the low price or the popularity of a particular brand and other reasons. According to Seth et al. (2005), customer retention is an effort to maintain a business relationship that occurs between service provider and customer. On the other hand, Gustafsson et al. (2005) state that the main factor of customer retention is customer satisfaction. Therefore the company must improve the quality of the products or services offered to the customer so that the customer feels satisfied. Based on these definitions, it can be concluded that customer retention is all activity directed by the company to maintain good and sustainable interaction with the customer. Hume (2006) mentions there are three indicators of customer retention variable are used, that are interested in reusing, and recommending to others and the company is a priority.

\section{METHODS OF RESEARCH}

The method used in this study is a cross-sectional design. Data obtained through an online survey are processed using a quantitative approach with descriptive analysis. The sampling technique in this study used purposive sampling, with 310 respondents obtained according to Slovin's calculation. The criteria for respondents are the customer who has a good history and already used car loan products or services at least once and for five years since the end of their credit period they never used credit again. Data collected through this study are primary data that include the characteristics of the customer, customer behavior, and customer retention in a car loan company. Customer retention is an effort to maintain a business relationship that occurs between a service provider and customer with three indicators that are interested in reusing, giving a recommendation to others, and the company being a priority. Data collection used a questionnaire with Likert scale and disseminated in the Google documents.

\section{RESULTS AND DISCUSSION}

Characteristics of Car Loan Customer. This study was conducted on 310 respondents 
who are a customer of company X. Gender is a critical component in marketing, but not all product and service can be differentiated according to this segment. Respondents from this study were dominated by men (82.3\%) with age $31-40$ years $(51.0 \%)$. According to the term and condition of the car loan that a person can make a car loan if he meets the criteria for adult age. Based on government regulation, a person is considered an adult age if he is twenty-one years old. If it is not yet twenty-one years old but already married, they included in the adult category. According to Schiffman and Kanuk (2008), the marital status of the respondents is one indicator in determining product to be sold. In this study respondent who had married had a higher percentage $(71.6 \%)$.

The level of education will significantly affect respondents in choosing the products or services. Also, a person's level of education will influence the values, way of thinking, perspective, and even his perception of a problem. The level of education in this study is divided into four groups, Senior high school, Diploma, Bachelor, and Master. In this study was dominated by Bachelor (65.5\%). In the second and third positions, the level of education was a Diploma (20.6\%) and Master (12.9\%).

A job can describe a person's social status. Besides, a job also affects a person's behavior in buying or using products or services. The job in this study is divided into six groups, student, government employee, office employee, entrepreneur, labor, and profession. The highest percentage of job respondents is in the office employee (43.2\%). The second position is occupied by respondents who work as an entrepreneur $(25.8 \%)$, and the lowest position is occupied by respondents with the labor (1.0\%).

Information about expenditure or allowance per month is needed to determine the economic background of the respondents. Based on this information, it can be seen which expenditure segmentation or allowance per month take the most car loan at company $\mathrm{X}$. The monthly expenditure in this study is divided into five range, Rp.1.000.001-2.000.000, Rp.2.000.001-3.000.000, Rp.3.000.001-4.000.000, Rp.4.000.001-5.000.000, and > Rp.5.000.000. Expenditure per month issued by respondents in this study are dominated by Rp.4.000.001-5.000.000 (54.8\%), the second position is Rp.3.000.001-4.000.000 (21.0\%), while the third position is > Rp.5.000.000 (15.5\%). The profile of the respondents in this study is presented in Table 1.

Table 1 - Profile of respondents based on demographic aspects

\begin{tabular}{|c|c|c|c|}
\hline Characteristics & Category & Amount $(n)$ & Percent (\%) \\
\hline \multirow[t]{2}{*}{ Gender } & Man & 255 & 82.3 \\
\hline & Woman & 55 & 17.7 \\
\hline \multirow[t]{4}{*}{ Age } & $<20$ Years & 14 & 4.5 \\
\hline & $20-30$ Years & 47 & 15.2 \\
\hline & $31-40$ Years & 158 & 51.0 \\
\hline & $>40$ Years & 91 & 29.4 \\
\hline \multirow{2}{*}{ Marital Status } & Married & 222 & 71.6 \\
\hline & Single & 88 & 28.4 \\
\hline \multirow[t]{4}{*}{ Education } & Senior High School & 3 & 1.0 \\
\hline & Diploma & 64 & 20.6 \\
\hline & Bachelor & 203 & 65.5 \\
\hline & Master & 40 & 12.9 \\
\hline \multirow[t]{6}{*}{ Job } & Office Employee & 134 & 43.2 \\
\hline & Entrepreneur & 80 & 25.8 \\
\hline & Government Employee & 60 & 19.4 \\
\hline & Profession & 19 & 6.1 \\
\hline & Student & 14 & 4.5 \\
\hline & Labor & 3 & 1.0 \\
\hline \multirow[t]{5}{*}{ Expenditure } & Rp.1.100.000-2.000.000 & 14 & 4.5 \\
\hline & Rp.2.000.001-3.000.000 & 13 & 4.2 \\
\hline & Rp.3.000.001-4.000.000 & 65 & 21.0 \\
\hline & Rp.4.000.001-5.000.000 & 170 & 54.8 \\
\hline & $>$ Rp. 5.000 .000 & 48 & 15.5 \\
\hline
\end{tabular}

Customer Car Loan Behavior. In this study, a vehicle is considered as one of the critical investment in life. Information about the respondent's vehicle ownership both from the 
number of vehicles owned and the brand is needed to find out how much the vehicle asset. Based on this information can be used as a reference for company $X$ to make new product according to the segmentation and vehicle brand preferred by respondents. This study result related to the number of vehicles owned is attached in Table 2.

Table 2 - Number of vehicles owned by respondents

\begin{tabular}{ccc}
\hline Number of Vehicles & Amount $(\mathrm{n})$ & Percent $(\%)$ \\
\hline 1 & 248 & 80.0 \\
2 & 54 & 17.4 \\
$>2$ & 8 & 2.6 \\
Total & 310 & 100.0 \\
\hline
\end{tabular}

In this study, the number of vehicles owned is divided into three groups, 1,2 , and $>2$ unit. Most respondents of company $X$ have one vehicle $(80.0 \%)$. The second position is occupied by a group of respondents who have two vehicles (17.4\%), and in the third position, only a small proportion of respondents have more than two vehicles (2.6\%). Besides that, in Table 3 will show the brand of vehicle owned by the respondents.

Table 3 - Brand of vehicle owned by respondents

\begin{tabular}{ccc}
\hline Brand & Amount $(\mathrm{n})$ & Percent (\%) \\
\hline Toyota & 197 & 63.5 \\
Daihatsu & 80 & 25.8 \\
Honda & 17 & 5.5 \\
Mazda & 7 & 2.3 \\
Nissan & 3 & 1.0 \\
Isuzu & 2 & 0.6 \\
Mitsubishi & 2 & 0.6 \\
Suzuki & 2 & 0.6 \\
Total & 310 & 100.0 \\
\hline
\end{tabular}

Vehicle brand in this study is grouped into Toyota, Daihatsu, Honda, Mazda, Nissan, Isuzu, Mitsubishi, and Suzuki. Based on the brand groups, most respondents had a vehicle with Toyota (63.5\%). The next position is that the respondents owned a vehicle with Daihatsu $(25.8 \%)$, and the third position is Honda (5.5\%). The result of this study shows that currently, most of the respondents still use the credit payment mechanism if they want to make a car purchase, which is attached in Table 4.

Table 4 - The number of vehicle purchased through credit

\begin{tabular}{ccccc}
\hline \multirow{2}{*}{ Number of Vehicle } & \multicolumn{3}{c}{ Percent $(\%)$} & \multirow{2}{*}{ Percent Total (\%) } \\
\cline { 2 - 4 } & 1 & 2 & $>2$ & 100.0 \\
2 & 100.0 & 0.0 & 0.0 & 100.0 \\
$>2$ & 16.7 & 83.3 & 0.0 & 100.0 \\
\hline
\end{tabular}

All respondents had one car that purchased on credit (100.0\%). Respondents who had two cars mostly bought both cars on credit (83.3\%), and only a few respondents bought one car through credit (16.7\%). Respondents who have $>2$ unit of cars, most of them buy two units of the cars on credit (62.5\%), and some respondents buy> 2 unit of cars using credit $(37.5 \%)$.

Several reasons cause the behavior of respondents preferred to use a credit mechanism than cash such as cashback, additional car accessories, and vehicle insurance protection during the credit period. Also, top of mind car loan companies, according to respondents are companies X, BCA Finance, and Mandiri Tunas Finance, which are attached in Table 5.

Respondents knew more about company X through sales dealer $(72.0 \%)$. Respondents knew more about BCA Finance from media print (37.2\%). Media information about Mandiri Tunas Finance mostly comes from friends $(32.3 \%)$. As it turns out at this time, most of the 
respondents were doing credit at BCA Finance (36.1\%). In the second position, the respondents stated that they were doing credit at BFI Finance (31.6\%) and in the third position, the respondent's credit at Mandiri Tunas Finance (21.0\%). The information is attached in Table 6.

Table 5 - Top of mind car loan company

\begin{tabular}{ccccccc}
\hline \multirow{2}{*}{ Car Loan Company } & \multicolumn{5}{c}{ Media Information (\%) } & \multirow{2}{*}{ Percent Total (\%) } \\
\cline { 2 - 5 } & Event & Family & Media Print & Sales dealer & Friends & 100.0 \\
Perusahaan $x$ & 12.4 & 6.8 & 1.9 & 72.0 & 6.8 & 100.0 \\
BCA Finance & 27.7 & 21.3 & 37.2 & 13.8 & 0.0 & 100.0 \\
Mandiri Tunas Finance & 27.4 & 11.3 & 29.0 & 0.0 & 32.3 & \\
\hline
\end{tabular}

Table 6 - Credit loan company currently use by respondents

\begin{tabular}{ccc}
\hline Credit Loan Company & Amount $(\mathrm{n})$ & Percent $(\%)$ \\
\hline BCA Finance & 112 & 36.1 \\
BFI Finance & 98 & 31.6 \\
Mandiri Tunas Finance & 65 & 21.0 \\
Mandiri Utama Finance & 35 & 11.3 \\
Total & 310 & 100.0 \\
\hline
\end{tabular}

The reason for respondents using BCA Finance because of low interest and installment. They had used it before, and the credit process was easy. BCA Finance has a lower interest rate compared to other credit companies with one to two percent interest rate gap. Besides, the most important program for respondents is attached in Table 7.

Table 7 - Special program interesting by respondents

\begin{tabular}{ccc}
\hline Special Program & Amount $(\mathrm{n})$ & Percent $(\%)$ \\
\hline Special Interest Rate & 133 & 62.4 \\
Loyalty Program & 63 & 29.6 \\
Credit Plafond & 17 & 8.0 \\
Total & 213 & 100.0 \\
\hline
\end{tabular}

A special program that is considered the most interesting by respondents is special interest rate $(62.4 \%)$ than a loyalty program $(29.6 \%)$ and credit plafond $(8.0 \%)$. If the respondents get a special interest rate, it will affect the installment per month that will be paid.

Customer Retention. There are three indicators of customer retention in this study which is attached in Table 8.

Table 8 - Customer retention indicator distribution

\begin{tabular}{cccc}
\hline \multirow{2}{*}{ Symbol } & Indicator & \multicolumn{2}{c}{ Percent (\%) } \\
\cline { 3 - 4 } & 1. Interested in reusing & Disagree & Agree \\
CR1 & 2. Giving recommendation to others & 18.3 & 81.7 \\
CR3 & 3. The company is a priority & 19.7 & 80.3 \\
\hline
\end{tabular}

The percentage of respondents answer according to the score level classification, and selection from each statement about customer retention show that in the first indicator most respondents $(81.7 \%)$ stated that they were using company $\mathrm{x}$ if there would apply for a car loan (CR1). In addition to the second indicator, most respondents (80.3\%) stated that they were willing to recommend company $x$ to others (CR2). The last indicator of most respondents $(83.4 \%)$ is willing to make company $x$ as a priority when they are going to apply for car loan again (CR3).

\section{CONCLUSION}

Most respondents of car loan company are men with age 31-40 years old and have married status. The education level of the majority of respondents is a bachelor degree with 
a job as an office employee who has expenditure Rp.4.100.000-5.000.000/month. Most of the respondents have one unit of the car with Toyota brand. For purchasing a car again, credit payment mechanism is still preferred than cash. Top of mind car loan companies is Company X, BCA Finance, and Mandiri Tunas Finance. Media information that is considered most useful for car loan companies is used sales dealer. Most of the respondents currently using BCA Finance because of this company have an interest and low installment. In line with this, the car loan program that considered attractive by respondents is special interest and installment. Regarding the customer retention, most of respondents are interested in reusing, recommending to others, and the company is a priority. Suggestions for further research should be able to conduct research on other financing product and use the segmentation of other respondents.

\section{REFERENCES}

1. Dawes J. 2009. The Effects of Service Price Increases on Customer Retention: The Moderating Role of Customer Tenure and Relationship Bread. Journal of Services Research. 11: 232.

2. Griffin J. 1995. Customer Loyalty, How to Earn It and How to Keep It. San Fransisco: Internet. [15 December 2018]. Available on: https://www.scirp.org/

3. Gustafsson A, Johnson MD, Roos I. 2005. The Effects of Customer Satisfaction, Relationship Commitment Dimensions and Triggers on Customer Retention. Journal of Marketing. 69: 210.

4. Hawkins D, Roger J, Coney. 2007. Consumer Behavior. New York: The McGraw-Hill Companies Inc.

5. Hume, Margee. 2006. Exploring Repurchase Intention in a Performing Arts Context: Who Comes? And Why Do They Come Back. International Journal of Nonprofit and Voluntary in Marketing Sector.

6. Kotler P. 2009. Marketing Management. Jakarta (ID): Gramedia.

7. Kurniawan D. 2018. Customer acquisition vs customer retention: [15 December 2018]. Available on: https://www.majalahfranchise.com/article/260/customer-acquisition-vsretention.

8. Lewis M. 2009. The Effect of Shipping Fees on Customer Acquisition, Customer Retention, and Purchase Quantities. Journal of Retailing. 82: 13-23.

9. Schiffman LG, Kanuk LL. 2008. Consumer Behavior. 7th Edition. Jakarta (ID): Indeks.

10. Seth N, Deshmukh SG, Vrat P. 2005. Service Quality Models: A Review. International Journal of Quality \& Reliability Management. 22(9): 913-949.

11. Solomon. 2007. Consumer Behavior: Buying, Having, and Being. NJ: Prentice Hall. 